\title{
The COVID-19 pandemic in the perspective of Indonesia's national security
}

\author{
Mir'atul Azizah ${ }^{1 *}$, Adi Subiyanto ${ }^{1}$, Sugeng Triutomo ${ }^{1}$, and Lexi Jalu Aji ${ }^{1}$ \\ ${ }^{1}$ Disaster Management Study Program, National Security Faculty, Republic of Indonesia Defense University, Indonesia
}

\begin{abstract}
Corona Virus Diseases 2019 or COVID-19 is a global problem and become a health problem in Indonesia seriously. Currently, in Indonesia, till June 27, 2021, the number of cases has reached 2,115,304, with 57,138 deaths and 1,850,481 healing. Every day the issues of COVID-19 tend to increase. The COVID-19 pandemic affects all sectors. It is the political, economic, sociocultural, defense and security sectors. Generally, this study analyzes COVID-19 from the national security perspective, in which one of the elements is human security. This study used a qualitative research method with a descriptive analysis approach to answering COVID-19 research problems from a national security perspective. This study indicated that COVID-19 impacts national security, military, political, economic, social, environmental, and human security. The government has released the regulations that arrange the community to mitigate the spread of COVID-19. The government has issued a vaccination policy to protect the public from COVID-19. The conclusion of this study, COVID-19 affects national security, both general security, and human security. The entirety handling of COVID-19 will enhance the sense of security of each citizen, especially in terms of human security.
\end{abstract}

\section{Introduction}

Corona Virus Diseases 2019 or COVID-19 is a global problem, including in Indonesia. The Indonesian government has even designated COVID-19 as a nonnatural national disaster by Presidential Decree Number 12 of 2020 [1].

The number of world COVID-19 cases until June 27, 2021 , reached $181,870,356$, with the number of cases dying 3,939,471 and recovering 166,382,287. Indonesia is one of 17 countries with the highest COVID-19 cases in the world. The number of cases in Indonesia currently reaches 2,115,304 with 57,138 deaths and 1,850,481 recoveries [2]. The rate of increase in COVID-19 cases cannot be said to be able to be suppressed. The trend of COVID-19 cases that continues to increase is an indication.

The impact of COVID-19 is vast, occurring in various fields of life [3] both in the political, economic, sociocultural, defense and security areas. It will undoubtedly affect the stability of the national.

The conception of national security is a condition that creates a sense of security, comfort, peace, tranquillity, and order. Security refers to state security in the face of military threats, public security, and safety from nonmilitary threaten [4]. Security is currently developing, not only military security but also non-military security, one of which is human security.
This study aims to analyze the response to the COVID-19 pandemic from a national security perspective. Then one of the elements is human security that will explain how this element influence life because of COVID-19.

\section{Methods and Data}

This study uses a qualitative method with a qualitative descriptive design. The source of the data used is primary data with in-depth interview techniques to the sources/informants. The study used secondary data in data/information from official reports from related agencies and literature studies.

\section{COVID-19 in Indonesia}

The first COVID-19 entered Indonesia, starting when two Indonesian citizens were exposed to COVID-19 after direct contact with foreign nationals visiting Indonesia. The Indonesian government also officially determined that COVID-19 had entered Indonesia on March 2, 2020 [5]. The government has developed strategies to protect the public from COVID-19, although the spread and transmission of COVID-19 in Indonesia are unstoppable. As previously stated, Indonesia is on the list of 17 countries with the highest COVID-19 cases globally, even number 1 in the Southeast Asia Region. Indonesia's

\footnotetext{
* Corresponding Author: miartul.azizah.sumitro@gmail.com
} 
territory and high population are factors in the high number of COVID-19 cases in Indonesia. The wider the area and the more residents, the higher the risk of the COVID-19 case.

Table 1. Number of COVID-19 casesin every Province of Indonesia as of June 6, 2021.

\begin{tabular}{|c|c|}
\hline Province & Number of Cases \\
\hline Jakarta & 435,135 \\
\hline West Java & 319,761 \\
\hline Central Java & 205,232 \\
\hline East java & 156,326 \\
\hline East Kalimantan & 72,114 \\
\hline Riau & 63,145 \\
\hline South Sulawesi & 62,347 \\
\hline Banten & 50,042 \\
\hline Bali & 47,472 \\
\hline Yogyakarta & 46,183 \\
\hline West Sumatera & 46,005 \\
\hline South Kalimantan & 35,043 \\
\hline North Sumatera & 32,528 \\
\hline South Sumatera & 25,213 \\
\hline Central Kalimantan & 23,090 \\
\hline Papua & 20,473 \\
\hline Bangka Belitung Islands & 19,126 \\
\hline Lampung & 18,735 \\
\hline Riau Island & 18,467 \\
\hline East Nusa Tenggara & 16,694 \\
\hline Aceh & 16,065 \\
\hline North Sulawesi & 15,816 \\
\hline Central Sulawesi & 12,971 \\
\hline North Kalimantan & 12,376 \\
\hline West Nusa Tenggara & 12,353 \\
\hline West Kalimantan & 11,504 \\
\hline Southeast Sulawesi & 10,538 \\
\hline Jambi & 10,104 \\
\hline West Papua & 9,397 \\
\hline Bengkulu & 8,340 \\
\hline Maluku & 7,793 \\
\hline West Sulawesi & 5,579 \\
\hline Gorontalo & 5,523 \\
\hline North Maluku & 4,548 \\
\hline
\end{tabular}

The cases of COVID-19 are increasing day by day, even new variants are emerging. It causes the number of COVID-19 instances to increase. The World Health Organization has also established a SARS-CoV-2 Risk Monitoring and Evaluation Framework to identify, monitor, and assess evolving variants. Surveillance, research on variants of concern, and impact evaluation on diagnostics, therapy, and performing vaccines [6].

The distribution of the number of COVID-19 cases in Indonesia in each province is different. The number of COVID-19 instances tends to be proportional to the population density of each area. The number of COVID19 cases in each province in Indonesia as of June 6, 2021, is shown in Table 1.

Based on Table 1, it can be seen that the province with the most COVID-19 cases in Jakarta with 435,135 cases, followed by West Java with 319,761 and Central Java with 205,232. The area with the lowest case was North Maluku, which was 4,548. It is proportional to the total population density in the province. The population density in 2019 in Jakarta was 15,900 people $/ \mathrm{km}^{2}$, West Java was 1,394 people $/ \mathrm{km}^{2}$, Central Java was 1,058 people $/ \mathrm{km}^{2}$, and North Maluku was 39 people $/ \mathrm{km}^{2}$ [8].

COVID-19 is transmitted through humans, so interactions between humans will increase the risk of COVID-19 transmission. Jakarta Province has the highest population density compared to other provinces in Indonesia, so it is only natural that the highest COVID-19 cases are in the Jakarta area.

A virus that circulates widely in a population and causes infection, the probability of viral mutation increases. The opportunity for the virus to spread is even more and more and more the virus is replicating and undergoing changes [6].

\section{Policies for Handling COVID-19 in Indonesia}

The Indonesian government issued various policies. The policies made are regulations that regulate and limit the public to prevent and reduce the risk of transmission and spread of COVID-19, including health services and vaccinations to all levels of society.

\subsection{Regulation}

The Indonesian government has issued various regulations since the emergence of COVID-19. The existing rules are shown in Table 2 based on CHCNER [9].

Table 2 shows that the government has issued product regulations since COVID-19 came to Indonesia. These regulations relate to health protocols, health services, education, economy, culture, politics, transportation, and so on. The government is concerned about the community's health and safety, so most of everything is regulated in regulations related to COVID-19. Regulation will be optimal if supported by people who understand the function and implement the rule correctly. 
Table 2. Indonesian Government regulations related to COVID-19 in 2020

\begin{tabular}{|c|c|c|}
\hline $\begin{array}{l}\mathrm{N} \\
\mathrm{o}\end{array}$ & Regulation & Date \\
\hline 1 & $\begin{array}{l}\text { The President of the Republic of } \\
\text { Indonesia Decree Number } 7 \text { of } 2020 \\
\text { concerning the Task Force for the } \\
\text { Acceleration of Handling COVID-19 }\end{array}$ & $\begin{array}{c}\text { March 19, } \\
2020\end{array}$ \\
\hline 2 & $\begin{array}{l}\text { The President of the Republic of } \\
\text { Indonesia Decree Number } 9 \text { of } 2020 \\
\text { concerning Amendments to the } \\
\text { Decree of the President of the } \\
\text { Republic of Indonesia Number } 7 \text { of } \\
2020\end{array}$ & $\begin{array}{c}\text { March 20, } \\
2020\end{array}$ \\
\hline 3 & $\begin{array}{l}\text { Government Regulation Number } 21 \\
\text { of } 2020 \text { concerning Large-Scale } \\
\text { Social Restrictions in the Context of } \\
\text { Accelerating Handling of COVID- } 19\end{array}$ & $\begin{array}{c}\text { March 31, } \\
2020\end{array}$ \\
\hline 4 & $\begin{array}{l}\text { Presidential Regulation of the } \\
\text { Republic of Indonesia Number } 54 \text { of } \\
2020 \text { and its Attachments regarding } \\
\text { Changes in Posture and the } 2020 \\
\text { Draft State Budget }\end{array}$ & $\begin{array}{c}\text { April 3, } \\
2020\end{array}$ \\
\hline 5 & $\begin{array}{l}\text { Regulation of the Minister of Health } \\
\text { of the Republic of Indonesia Number } \\
9 \text { of } 2020 \text { concerning Guidelines for } \\
\text { Large-Scale Social Restrictions in the } \\
\text { Context of Accelerating Handling of } \\
\text { COVID-19 }\end{array}$ & $\begin{array}{c}\text { April 3, } \\
2020\end{array}$ \\
\hline 6 & $\begin{array}{l}\text { Regulation of the Minister of } \\
\text { Transportation of the Republic of } \\
\text { Indonesia Number } 18 \text { of } 2020 \\
\text { concerning Transportation Control in } \\
\text { the Context of Preventing and } \\
\text { Preventing the Spread of COVID-19 }\end{array}$ & $\begin{array}{c}\text { April 9, } \\
2020\end{array}$ \\
\hline 7 & $\begin{array}{l}\text { Decree of the President of the } \\
\text { Republic of Indonesia Number } 12 \text { of } \\
2020 \text { concerning the Designation of } \\
\text { Non-Natural Disasters COVID-19 as } \\
\text { a National Disaster }\end{array}$ & $\begin{array}{c}\text { April 13, } \\
2020\end{array}$ \\
\hline 8 & $\begin{array}{l}\text { Regulation of the Minister of } \\
\text { Transportation of the Republic of } \\
\text { Indonesia Number } 25 \text { of } 2020 \\
\text { concerning Transportation Control } \\
\text { During Eid Al-Fitr Homecoming } \\
\text { Year } 1441 \mathrm{H} \text { in the Context of } \\
\text { Prevention and Prevention of the } \\
\text { Spread of COVID-19 }\end{array}$ & $\begin{array}{c}\text { April 23, } \\
2020\end{array}$ \\
\hline 9 & $\begin{array}{l}\text { Presidential Regulation of the } \\
\text { Republic of Indonesia Number } 82 \text { of } \\
2020 \text { concerning the Committee for } \\
\text { Handling COVID-19 and National } \\
\text { Economic Recovery }\end{array}$ & $\begin{array}{c}\text { July 20, } \\
2020\end{array}$ \\
\hline 10 & $\begin{array}{l}\text { Presidential Regulation of the } \\
\text { Republic of Indonesia Number } 99 \text { of } \\
2020 \text { concerning Vaccine } \\
\text { Procurement and Vaccination } \\
\text { Implementation in the Context of } \\
\text { Coping with COVID-19 }\end{array}$ & $\begin{array}{c}\text { October 6, } \\
2020\end{array}$ \\
\hline 11 & $\begin{array}{l}\text { Regulation of the Minister of Health } \\
\text { of the Republic of Indonesia Number } \\
84 \text { of } 2020 \text { concerning the } \\
\text { Implementation of Vaccination in the } \\
\text { Context of Coping with COVID-19 }\end{array}$ & $\begin{array}{c}\text { December } \\
14,2020\end{array}$ \\
\hline
\end{tabular}

The regulatory function [10] controls social [11]. The regulatory function will run well if the human resources who perform the regulatory function understand and are skilled [12]. Local governments also adjust to the regulations made by the central government. They socialize with the public either directly, the media, or other parties so that all the rules reach the community.

\subsection{Health Services}

Health services during the COVID-19 pandemic are very important. Through the Ministry of Health, the government has appointed several hospitals in each region as referral hospitals for COVID-19 patients. The government wants the people who need health services, especially those related to COVID-19, can be handled quickly and increase their chances of recovering.

Jakarta currently has 106 referral hospitals for COVID-19 [13]. At the end of last year, there were 90 referral hospitals [14]. It is an indicator that more and more COVID-19 patients in Jakarta need treatment. As the area with the most COVID-19 cases, Jakarta is trying hard to keep its people safe from COVID-19. One of them is by adding referral hospital facilities for COVID-19.

The government has prepared to allocate a special budget for free treatment for COVID-19 patients in government-owned hospitals. The government hopes that people from all walks of life will have the same opportunity to recover with this policy.

Doctors and nurses are at the forefront of direct contact in treating patients [15]. COVID-19 attacks everyone, both the general public and medical personnel. Medical personnel directly deal with patients, so they are also at high risk of contracting COVID-19. One by one, medical personnel died due to exposure to COVID-19. They are the saviors of the patients, but on the other hand, they also cannot refuse to be exposed to COVID-19

\subsection{Vaccination}

Vaccination is one of the Indonesian government's efforts to protect the public from COVID-19. The vaccines used are not produced by themselves. It is also a challenge for Indonesia, which has been independent for 75 years.

The COVID-19 vaccine is expected to protect against new virus variants. The development of vaccine effectiveness is continually monitored [6]. The success of a vaccination program is the responsibility of all, whether individuals, health professionals, government, or industry [16].

Indonesians have started receiving the COVID-19 vaccine. The number who have implemented the first vaccine is $17,775,918$ of the $181,554,465$ targeted or $9.79 \%$. The second vaccination was $11,197,069$ people from the target of $40,349,049$ targets or $27.75 \%$. This amount is vaccination as of June 7, 2021 [7]. Vaccine priority is given in stages, starting from health workers, public service workers, and the community.

Vaccine effectiveness is affected by its coverage, access to health centers, costs, and other factors [16]. The government provides free COVID-19 vaccines to the 
public. Exceptions are given to pregnant women, the elderly, and people with comorbidities. The implementation of vaccination is expected to achieve all that has been targeted.

Vaccination is not a sure guarantee of being safe from COVID-19. People who have received the vaccine must still carry out health protocols, namely wearing masks, washing hands with clean water and soap, maintaining distance, not crowding and reducing mobility, and consuming nutritious food.

\section{Impact of COVID-19 on National Security}

One of the state's goals based on the preamble to the Constitution of the Republic of Indonesia is to protect the entire Indonesian nation. The word save has a broad meaning, including protecting its citizens from all threats, including the danger of non-natural disasters COVID-19

The COVID-19 pandemic has affected the economic sectors of countries in the world, including Indonesia. The health sector is challenged to solve this condition. Other sectors were also affected, such as politics, society, and culture. It has an impact on national defense and security.

Security is one of the focuses of attention to be achieved by all parties. It is what makes the issue of national security a vital thing in a country. State behavior in anticipating threats to its national security by using a military approach states behavior in anticipation threats to its national security by using a military approach dominates the security. Now, the concept of national security developed. Security includes five main sectors, namely (a) military security, (b) political security, (c) economic security, (d) societal security, and (e) environmental security [17].

\subsection{The Military Security}

Military security includes the management of the state's weapons capabilities both offensively and defensively and the state's perception of the intensity of one another [17]. The military is the primary national security and defense force, both in human resources, defense equipment, systems, and other resources.

COVID-19 is a non-military threat, so the government appoints non-military institutions. The National Disaster Management Agency (NDMA) and the Ministry of Health are the leading sectors in dealing with the COVID19 pandemic. NDMA and the Ministry of Health are working hard and working smart to protect the public from COVID-19.

COVID-19 is not just a non-military affair. The military is still involved in dealing with COVID-19. The military's involvement in handling COVID-19 includes contributing to the provision of humanitarian assistance.

As part of the military, Indonesian National Army (INA) is at the forefront of mitigating COVID-19. It can be used as an indicator in measuring Indonesia's defense strength against the threat of disease outbreaks, including COVID-19. The TNI provides health services for COVID-19 through the deployment of health units, including the Army Strategic Reserve Command Health Battalion, Marine Health Battalion, and the Air Force Health Battalion Headquarters [18].

Indonesian National Army is also involved in enforcing discipline in the implementation of health protocols. The military's involvement in handling COVID-19 brings people's trust in the government. INA, as the main component in security and defense, makes people feel more secure.

\subsection{The Political Security}

Political security focuses on the stability of the state organization, the ideological system that gives legitimacy to the government [17]. At this level, the government, through the National Disaster Management Agency and the Ministry of Health, is trying very hard to free the Indonesian people from COVID-19 immediately.

Indonesian politics is still within safe limits. All Ministries/Agencies cooperate to overcome COVID-19 and its impacts.

\subsection{The Economic Security}

Economic security includes access to resources, finance, and markets to support good welfare and state power [17]. COVID-19 has caused a decline in economic activity such as household consumption, investment, and financial institutions in Indonesia [3].

The Indonesian government has spent a large amount of money on efforts to prevent and deal with COVID-19. The government also revised the budget several times to meet these needs.

Significant impacts occur on the global economy, including economic stability in Indonesia [19]. COVID19 pandemic has been running for more than a year, the Indonesian economy has weakened and is now starting to rise

Indonesia's economic recovery began to be seen in the second semester of 2020 and is predicted to continue in 2021. Progress in handling COVID-19, including vaccines, global economic recovery, macroeconomic policy stimulus policies, and various policy sharpening efforts that support the optimization of the economic recovery [20].

\subsection{The Societal Security}

Societal security includes traditional language, culture, religion, national identity, and customs [17]. COVID-19 is spread by human intermediaries, namely through close contact, droplets when coughing, sneezing, or talking [21]. High community mobility will lead to a higher risk of COVID-19 transmission. It makes people more aware of both themselves and the environment.

The social life of the community has been affected by COVID-19. Societies that previously interacted freely changed, limiting interactions. The education system also adapts, namely online learning. Silaturahmi (meeting each other) during Ramadhan (fasting month) and Eid Al-Fitr (holy days) that are usually done in person, is now turning 
online. Large-scale social restrictions were also implemented in almost all regions in Indonesia.

At the beginning of the emergence of COVID-19, people were apprehensive if there were neighbors in the same area who experienced COVID-19. They are afraid of getting infected, but over time people begin to understand and even help each other to get well soon

Sufficient social support from the environment affects the desired goals [22], in this case recovering from COVID-19. Indonesian people have local wisdom "gotong royong" or a form of cooperation. The community helps each other when COVID-19 infects a neighbor or family. They provide support in the form of motivation to recover and help provide food for daily needs during self-isolation

\subsection{The Environmental Security}

Environmental security focuses on maintaining the environment both locally and globally as essential support for the system in which humans live [17]. COVID-19 affects the environment, both in the environment where you live, where you work, and the environment in general.

The COVID-19 pandemic has forced people to wear masks and hand sanitizers. The impact of using masks and hand sanitizers is the accumulation of medical waste in the form of used masks and hand sanitizers.

Medical waste management is critical because it can pose a high risk to human health and the environment [23]. Medical waste processing in hospitals or other medical services has become commonplace because they usually have a third party to manage. How is the waste processing, both in the household, village or sub-district, sub-district and even at the national level? It is something that needs further attention. Medical waste that is not managed correctly will certainly cause environmental damage and other impacts.

\subsection{The Human Security}

The five security sectors described above are military, political, economic, social, and environmental security contain human security. Human security is part of national security.

Security means being free from insecurity and threats. Safe is free from fear and lack. Anxiety is due to physical, psychological violence, abuse, or death while lacking work, food, and poor health [24]. Human security, including freedom from threats and fear of COVID-19.

Human security is the right of every citizen. They have the right to feel safe, not afraid of COVID-19 or its effects. They also have the right to feel adequate in food, health services, including work. COVID-19 has frightened people. They are scared of contracting and transmitting it. They are also scared of the worst risk if they get COVID19, which is death. They see the updating of COVID-19 cases increasing, and the number of deaths is increasing every day. It added their fear.

Households are the sector most affected by COVID19 [19]. Some people have lost their jobs because the places where they work have decreased demand and even lost money. Those who rely on their income from trading also experience a decrease in income or even none at all. Examples of traders in the canteen or around schools and campuses stop because education is currently carried out online.

\section{Conclusion}

COVID-19 has affected all aspects of people's lives globally, including in Indonesia. The impact of COVID19 has occurred in almost all sectors. National security is one of the most important things because it is related to national stability. COVID-19 affects military, political, social, environmental, and human security. The human security aspect of the community will be threatened. COVID-19 has been affecting their lives. Society must fight harder to survive and be safer from COVID-19. The Indonesian government issued policies in regulations and vaccinations to protect the public from COVID-19 to be safer. The government has also mobilized non-military and military institutions to deal with COVID-19 jointly. These are government efforts in realizing Indonesia's national goal, which is to protect all citizens, especially from the threat of COVID-19. National security is a shared responsibility, both government and society. The government is preparing all its strategies so that the community is safe, including safe from COVID-19. We, as citizens, are supposed to comply with all government policies. One thing that needs more attention is environmental safety in managing medical waste from used masks and bottles of hand sanitizer used by the general public. Safe in the political, military, economic, social, and environmental is the dream of all of us.

\section{References}

1. Decree of the President of the Republic of Indonesia Number 12, in 2020 (n.d.)

2. Worldometers, (2021)

3. P. B. Astuti and A. S. Mahardhika, J. Inov. Ekon. 5, 85 (2020)

4. B. Darmono, J. Ketahanan Nas. 15, 1 (2010)

5. M. H. Sukur, B. K. Haris, and R. N. Faradillahisari, Inicio Legis 1, 4 (2020)

6. World Health Organization, (2021)

7. Committee for Handling COVID-19 and National Economic Recovery, (2021)

8. Bureau of Statistics Center, (2021)

9. Committee for Handling COVID-19 and National Economic Recovery, (2021)

10. A. Fitri, L. Trisnantoro, and D. H. Sulistyo, J. Kebijak. Kesehat. Indones. 03, 3 (2014)

11. A. Shleife, Eur. Financ. Manag. 11, 442 (2005)

12. T. Sukarma, Designing a Health Service Regulatory System in the Provinces of DIY and West Java (2005)

13. Kompas, (2021) 
14. Decree Of The Governor Of Jakarta The Capital Of Region, (2020)

15. R. N. Putri, J. Ilm. Univ. Batanghari Jambi 20, 708 (2020)

16. M. Doherty, P. Buchy, B. Standaert, C. Giaquinto, and D. Prado-Cohrs, Vaccine 34, 6707 (2016)

17. B. Buzan, People, State, and Fear: An Agenda for International Security Studies in the Post-Cold War (1991)

18. A. Octavian, IOP Conf. Ser. Earth Environ. Sci. 708, (2021)

19. S. Susilawati, R. Falefi, and A. Purwoko, Budapest Int. Res. Critics Inst. Humanit. Soc. Sci. 3, 1147 (2020)
20. Bank of Indonesia, Indonesia Economic Report 2020 "Synergy to Build Optimism for Economic Recovery" (2021)

21. M. Khan, H. Khan, S. Khan, and M. Nawaz, J. Med. Microbiol. 69, 1114 (2020)

22. E. Tezci, F. Sezer, U. Gurgan, and S. Aktan, Anthropologist 22, 284 (2015)

23. Z. M. Shareefdeen, J. Environ. Prot. (Irvine, Calif). 03, 1625 (2012)

24. S. Tadjbakhsh, Human Security: Concepts and Implications with an Application to Post-Intervention Challenges in Afghanista (2005) 